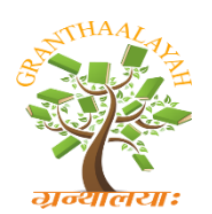

\author{
INTERNATIONAL JOURNAL OF RESEARCH - \\ GRANTHAALAYAH \\ A knowledge Repository
}

Management

\title{
GOVERNANCE TERRIORIAL IN FAVOR OF SUSTAINABLE TOURISME, PROPOSITION OF A MULTI-SCALE GRID CASE OF ZAGHOUAN REGION, TUNISIA
}

\author{
Salma Sioud ${ }^{* 1}$, Hichem Rejeb ${ }^{2}$ \\ ${ }^{* 1,2}$ Higher Agronomic Institute of Chott Mariem - Sousse University, Sousse, Tunisia
}

DOI: https://doi.org/10.29121/granthaalayah.v5.i3.2017.1767

\begin{abstract}
This research focuses on the enhancement of natural and cultural landscapes to ensure tourism subsequently as an income generating activity in areas with difficulties. Even if in these areas the potential is high and the willingness of officials and other actors is strong to make tourism an activity that can help local population, success is long in coming. This study helps to highlight the importance of territorial governance for sustainable tourism in Tunisia. Territorial governance has become a central issue in tourism development and a challenge for public policy. Thus, the present study is to show how to evaluate territorial governance taking into account the interactions between the resource territory, local development policies and tourism. The integration of territorial governance principles in sustainable tourism development is one of the most important issues of this activity; in the center of several visions and practices of conservation, negotiating dynamics of the specific objectives of each of the concerned actors in ecotourism development seems to be conflicted between environmental and socio-economic concerns and converging and diverging interests.
\end{abstract}

Keywords: Territorial Governance; Sustainable Tourism; Evaluation; Participation.

Cite This Article: Salma Sioud, and Hichem Rejeb. (2017). "GOVERNANCE TERRIORIAL IN FAVOR OF SUSTAINABLE TOURISME, PROPOSITION OF A MULTI-SCALE GRID CASE OF ZAGHOUAN REGION, TUNISIA." International Journal of Research - Granthaalayah, 5(3), 180-192. https://doi.org/10.29121/granthaalayah.v5.i3.2017.1767.

\section{Introduction}

Having a great interest in the issue of development of disadvantaged rural areas in Tunisia and based on the observation of the great difficulties that actors face in these areas to set up a development process there, it is proposed through this study to report our thinking on sustainable tourism development in these fragile zones and understand the rules and strategies of the actors involved in the development process and the relationship between the governance and its effect on the degree of specific resources enhancement. This field of analysis is applied to develop the 
sustainable tourism in the area of Zaghouan. Indeed, tourism is an essential vector of the national economy; Tunisia has a very diverse mosaic of natural and cultural landscapes that has encouraged the emergence of this activity, especially in the coastal areas of the territory. Tourism management was initially accentuated by the promotion of seaside tourism. Second, and with the integration of the notion of sustainable development, the State has turned towards the development of alternative tourism. (Ferchichi, 2011).

This research is part of a socio-political sustainable development analysis applied to the tourism sector or the analysis of territorial governance in sustainable tourism. The main mission of this research is to understand the dynamics of the negotiation of each actor involved in sustainable tourism development to know the dynamic of their negotiations on territory. The economic and social development of the governorate of Zaghouan depends on an intense mobilization of natural resources of the region. This mobilization has implications for the balance and sustainability of natural resources. Moreover, and despite efforts to diversify the regional and local economy, the region has maintained its agricultural vocation. The establishment of certain economic sectors (manufacturing, administrative and non-administrative) was not able to create sufficient momentum to alleviate the pressure of the agricultural sector. (Riahi and Rezig, 2011). On the other hand, the region is characterized by abundant rural settlement; the problems in this area relate to the standard of living of the inhabitants and their isolation from urban areas. This isolation has shaped a non-open and non-creative population of development projects faced with endangered resources.

We hypothesize that this delay in the start of tourism is linked to difficulties due to local and central dysfunctions, particularly in terms of governance.

The theoretical framework developed, analyses sustainable tourism as a form of multidimensional tourism development that places particular emphasis on the governance dimension, a dimension where the final balance is the result of negotiation between the interveners. (Breton 2009)

The choice of a tourism that values resources as well as possible while preserving them seems essential for it to become a tool for the sustainable development of this fragile territory. As such, a sustainable, territorial and cross-sectored tourism strategy that takes into account socioeconomic imperatives and compliance with environmental requirements should be put in place.

\section{Materials and Methods}

\subsection{From Concept to Action: The Multi-Scale Grid}

The concept of territorial governance, sometimes rather abstract, has an uncertain perimeter and an imprecise content and requires means of evaluation to give it a more concrete and operational form. For this, the choice of a reliable methodological tool seems necessary to understand the situation and then to pilot and manage the development of tourism through the implementation of a strategy. Our choice was based on the multi-scale analysis grid, inspired directly by the grid RST02 1, adjusted to the specificities of our territory and our work objectives. In an operational approach, the multi-scale grid presents itself as a tool for questioning and analysis and decision 
support through the implementation of a sustainable tourism strategy. We will illustrate its operationalization based on the field work carried out in the Zaghouan region.

${ }^{1}$ The Grid RST02 was designed in 2007 by the Scientific and Technical Network led by the Technical Studies Centers of Equipment and by the CERTU (Center for studies on Networks, Transport, Urban Planning and public buildings)

Its evaluation process makes it possible to define objectives for the actors concerned by facilitating and making more practicable the implementation of a touristic planning based on the concept of territorial governance.

\subsection{The Functioning of the Multi-Scale Grid}

This grid has been tested in different contexts giving results that have met the expectations of users wishing to engage in a sustainable development approach.

This evaluation grid was carried out by integrating the following elements:

- Our previous research work which is part of the project "Establishment of an eco-touristic network of natural spaces in Mediterranean countries of North Africa" developed by the International Union for the Conservation of Nature (IUCN ) to improve decision-making and planning and management of ecotourism activities in and around the Jebel Zaghouan National Park.

- The parameters resulting from the global and integrated diagnosis of the strengths and constraints of the Zaghouan region,

- Field surveys carried out among the local populations in various communes of the governorate,

- Grid RST02, a tool for questioning and analysing sustainable development criteria developed by the scientific and technical network of the French Ministry of Ecology, Sustainable Development and Energy.

\subsubsection{The Questioning Guide}

In order to inform the actors, each criterion is analysed using a set of specific questions, forming a questioning guide. This fieldwork tool is intended to "make speak" the criteria, to sound them, to examine them under their facets. Through this guide, the user quickly exposes a project, highlights its strengths and weaknesses.

\subsubsection{The Rating System}

Sustainable development sometimes raises new questions, hence the importance of providing benchmarks, thus enabling actors or companies to learn and situate themselves in relation to sustainable development, which will also allow them, in the first instance, to measure the relevance of the actions undertaken or to be undertaken in relation to territorial changes and then, in a second phase, to take steps to move towards the same sustainable development. The grading system also called "scale of appreciation", allows to evaluate an action, giving it a value which 
aims to evaluate its sustainability as a function of time, while re-adapting the action plan according to the evolutions.

Table 1: The scoring system on a scale from 0 to 4

\begin{tabular}{ll}
\hline Note & \multicolumn{1}{c}{ Correspondance level } \\
\hline $\mathbf{0}$ & Criterion incorrectly taken into account or absent \\
$\mathbf{1}$ & Criterion with an objective achievement or weakly taken into account \\
$\mathbf{2}$ & Criterion in progress or moderately taken into account \\
$\mathbf{3}$ & Criterion achieved or well taken into account \\
$\mathbf{4}$ & Criterion verified or very well taken into account \\
\hline
\end{tabular}

\subsubsection{The Performance Chart}

Consisting of a pre-filled table, the performance table guides the analysis work step by step through the criteria of the grid. To do this, the user must review the list of criteria concerned in relation to the corresponding rating scale.

\subsection{Graphical Analysis of the Grid}

During this stage, thanks to the modules and graphical outputs specially developed in Microsoft Excel, the results by dimension (economic, social, etc.) are presented in the form of a fourbranch graph (Radar). From the averages of each dimension, the tool provides a synthetic image of the final rendering called "sustainable development profile". The position of the edges of the profile at the right of the axes corresponds to the respective averages of the selected dimensions: social, economic, environmental, governance.

Each branch corresponds to the averages of the four dimensions studied. They form an envelope whose surface is more or less important. The larger the area, the more sustainable the project is.

\subsubsection{The Staircase of Governance}

The multi-scale grid treats governance separately. This choice results from the fact that governance can be applied to the other axes (economic, environmental, and social) and is more a common hat than an additional axis. The governance dimension is represented by a horizontal bar whose axis is adjusted in the manner of a staircase composed of four distinct steps. The average of the governance is materialized by showing of the stair- ranking in the staircase. A horizontal line separates the negative stairs from the positive stairs, thus tracing the ground floor (level 2). The average of the governance can take an integer value (integer ranging from 0 to + 4), the stair being entirely coloured, in relation to its level of filling. It can also equal a decimal value to the nearest quarter point; the stair is then more or less saturated with the reference colour in proportion to the corresponding decimal fraction (CERTU, 2006). The governance position is easily identifiable on the staircase. The rank and level of filling of the stair allows us to situate the effort that must be made to set up an additional stair and progress in governance. 


\subsection{An Analytic Grid for Who?}

Our methodological choice fell on tourist companies and associations, because these two actors are largely represented on the set area. Likewise, the touristic business offers a global picture of the confronting interests; putting together the project leader, the employee and the tourist that are in their turn in close relationship with the resource territory, the local population and local decision makers.

Table 2: Selected actors in sustainable tourism

\begin{tabular}{cc}
\hline Institution & $\begin{array}{c}\text { Activity area } \\
\text { Dar Zaghouan }\end{array}$ \\
Ksar Ezzite & country cottage \\
les nymphes & country cottage \\
Jebel el oust & health resort \\
Sirroko & travel agency \\
Bécasse & travel agency \\
Tunisian Travel Service & travel agency \\
passion voyage & travel agency \\
& Associations \\
ASEZ & speleology \\
ATPNE & environment \\
AREZ & hiking /environment \\
Nesri & promotion of wild roses \\
spéléo club & speleology / environment \\
sport pour tous & sport/environment \\
\hline
\end{tabular}




\section{Results and Discussions}

\subsection{Analyze of Multi - Scale Grid Results}

\section{Table 3: Multi-scale grid results of selected actors (social and economic dimensions)}

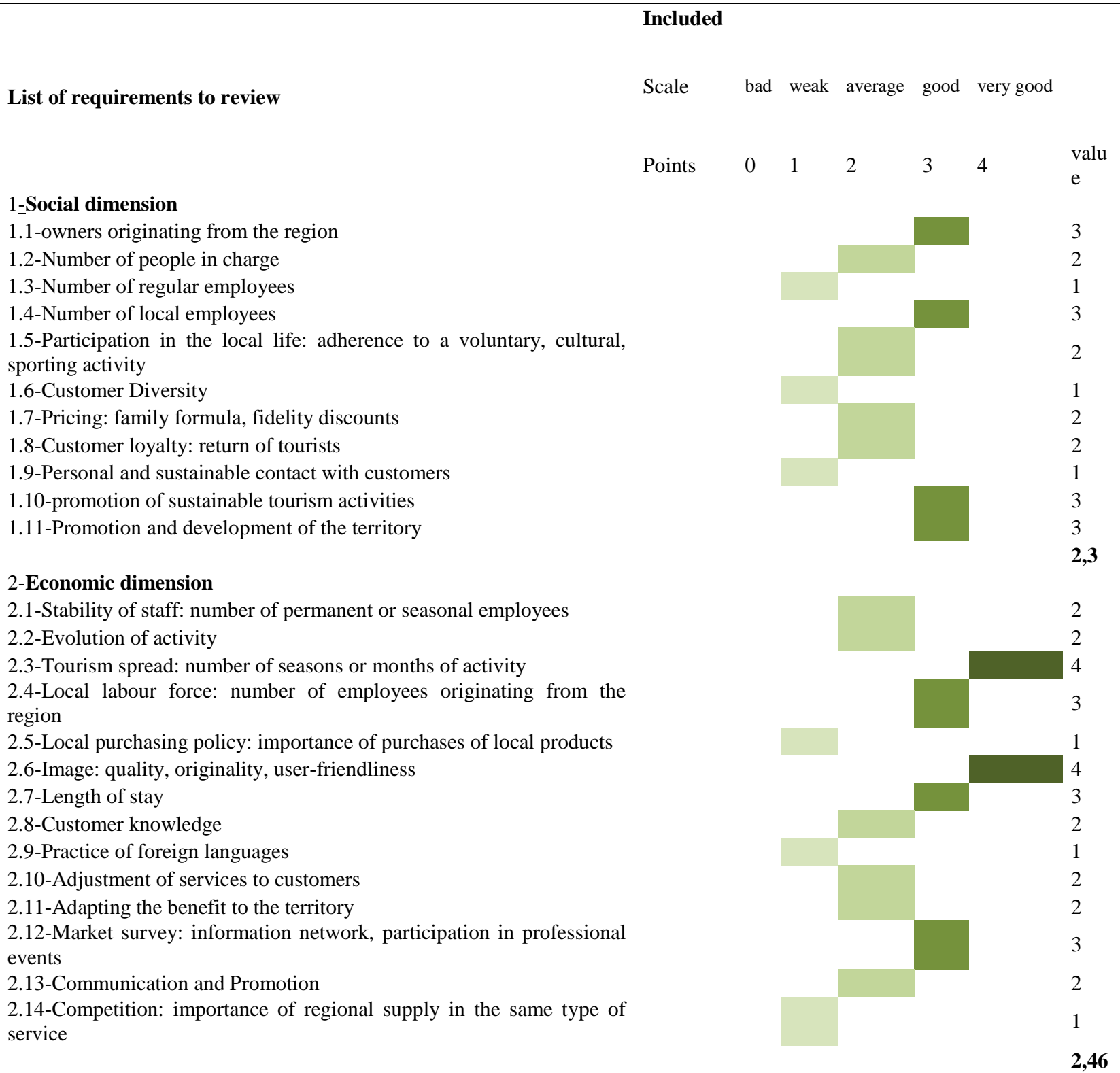


Table 4: Multi-scale grid results of selected actors (environmental and governance dimensions)

\section{List of requirements to review}

\section{3-Environmental dimension}

3.1-Respect for the environment

3.2-Environmental education

3.3-Conservation of the traditional style and typical local products

3.4-Renovation of old buildings or setting in defence

3.5-Traditional lifestyle

3.6-Promotion of tradition site and the territory

3.7-Associative life

3.8-Landscape sensitivity: Landscape integration of the built environment

3.9-Conservation of traditional space management practices

3.10-Water Consumption: Whether or not there are saving measures

3.11-Energy consumption: heating mode, use of renewable energy (solar)

3.12-Treatment and sorting of solid and liquid waste

3.13-Sensibilisation of tourists to the impacts of waste

\section{4-Dimension Governance}

4.1-Modalities of decision-making

4.2-Methods of monitoring and quality control of products and activities / services

4.3-Transparency vis-à-vis the employee around his / her employment contract

4.4-Transparency on company results

4.5-Solidarity: company assistance to employees (adaptation of working hours, housing assistance, support for training...)

4.6-Working with Tour Operators

4.7-Working with social networks; association, ONG

4.8 - Authenticity of the services

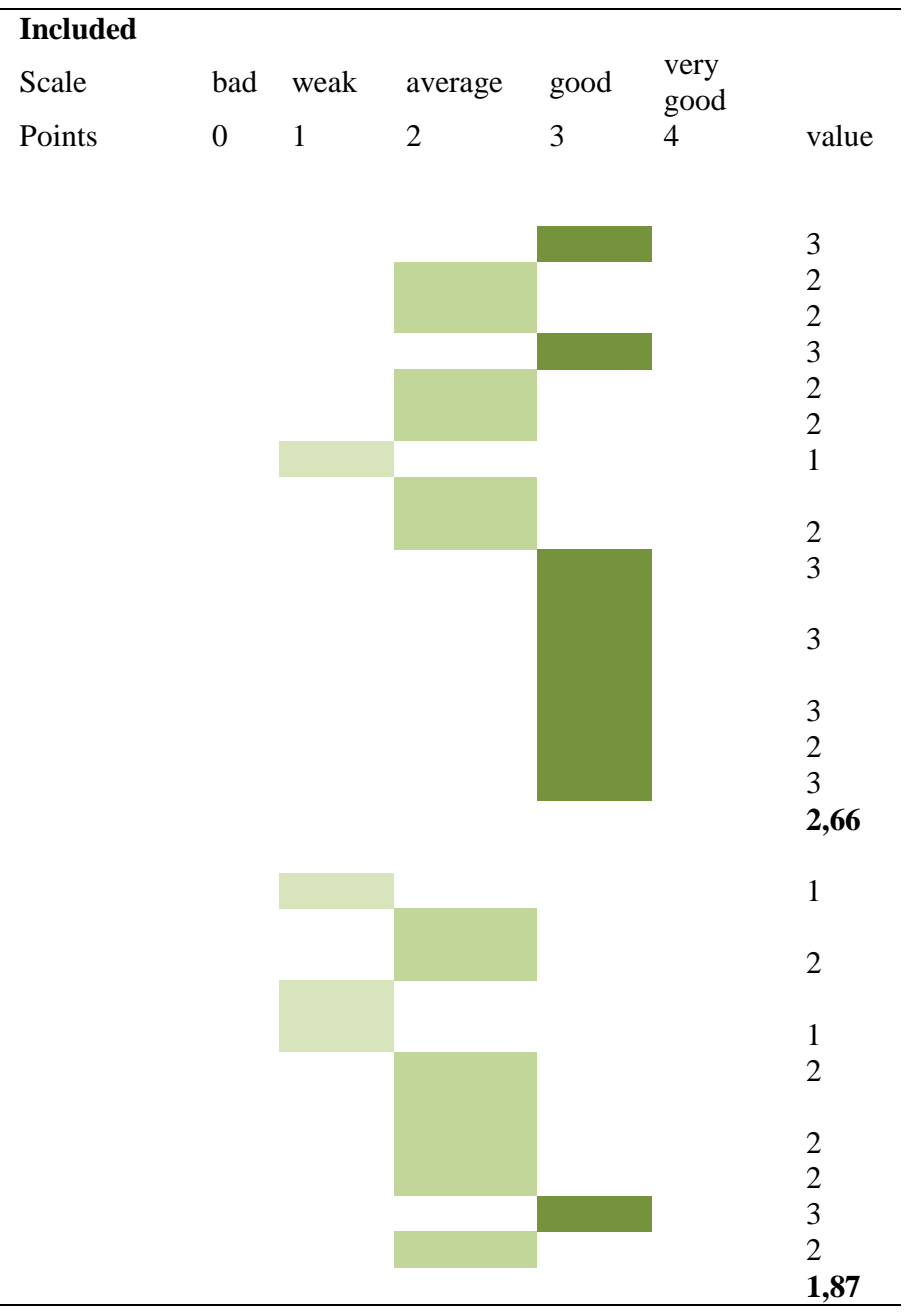

\subsubsection{Graphical Analysis of the Grid}

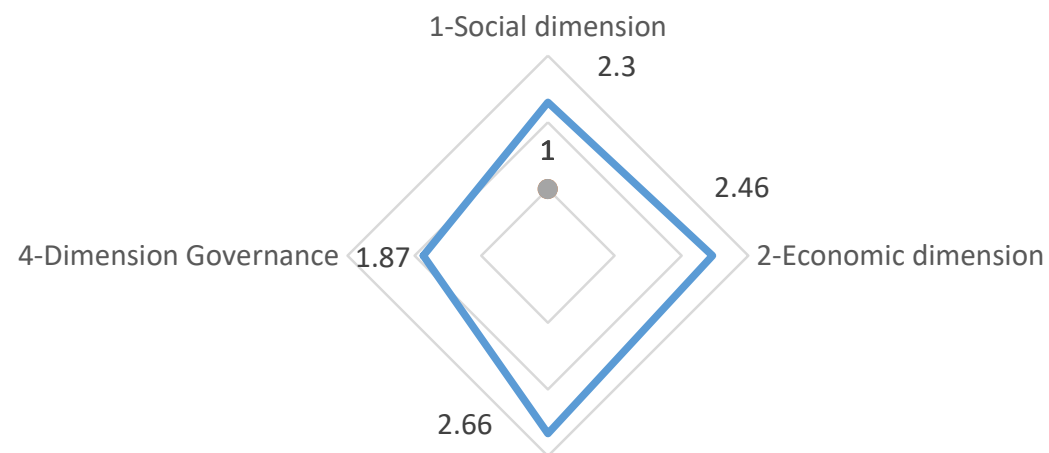

3-Environmental dimension

Figure 1: The profile of sustainable development for all selected actors 
The graphical analysis of the results of the grid makes it possible to identify these observations:

\section{At The Economic Level}

The analysis of the investigations reveals that the offer of sustainable tourism is very low in terms of accommodation, rather positive in terms of tourism activities. The distribution of income generated by this economic activity also appears to be weak.

The employment resulting from the tourist activity only partially benefits the local population. Thus, we cannot speak of a flourishing of the local economy but rather of low-paying and highly seasonal jobs. This is one of the main faults of tourism which is struggling to integrate with local development.

As for associations, they have all included sustainable tourism as a priority in their activities and they hope to be able to disseminate their actions in the municipalities.

The Tunisian Association for the Protection of Nature and the Environment (ATPNE), which aims to work for the protection of the environment, sees sustainable tourism as a means of improving the incomes of local populations, which could help to reduce anthropogenic pressures on the mountain.

\section{At The Environmental Level}

Tourism as practiced in our study area amplifies questions about the conservation of existing resources such as the abundance of water resources and the richness of animal and plant biodiversity; the efforts made for the management of environmental resources by tourism companies are estimable, this is perfectly due to the context of sustainable tourism in which we are located.

Associations are actors playing a leading role in protecting the environment. They are animated by the spirit of volunteering, the concern to defend nature and represent a hard core in regional ecological policy; (AREZ), which works to improve environmental quality in the vicinity of Sidi Bougabrine, and the Tunisian Association for the Protection of Nature and the Environment (ATPNE), which provides the establishment of a project to improve the quality of the landscape and minimize the risks of fires, and puts in place actions to promote sustainable tourism.

\section{At The Social and Organizational Level}

The model of tourism developed in the Zaghouan region appears fragile, with in particular a weak involvement of the local population and its representatives in the management of tourism matters.

Often voluntary to participate in the development of tourism, the inhabitants expect tourism economic spin-offs and the improvement of living conditions in the villages and in the homes. 
The sector still suffers from certain weaknesses, both upstream and downstream, with a lack of coordination of synergies between local actors, which seriously threatens the success of tourism policies in the regions.

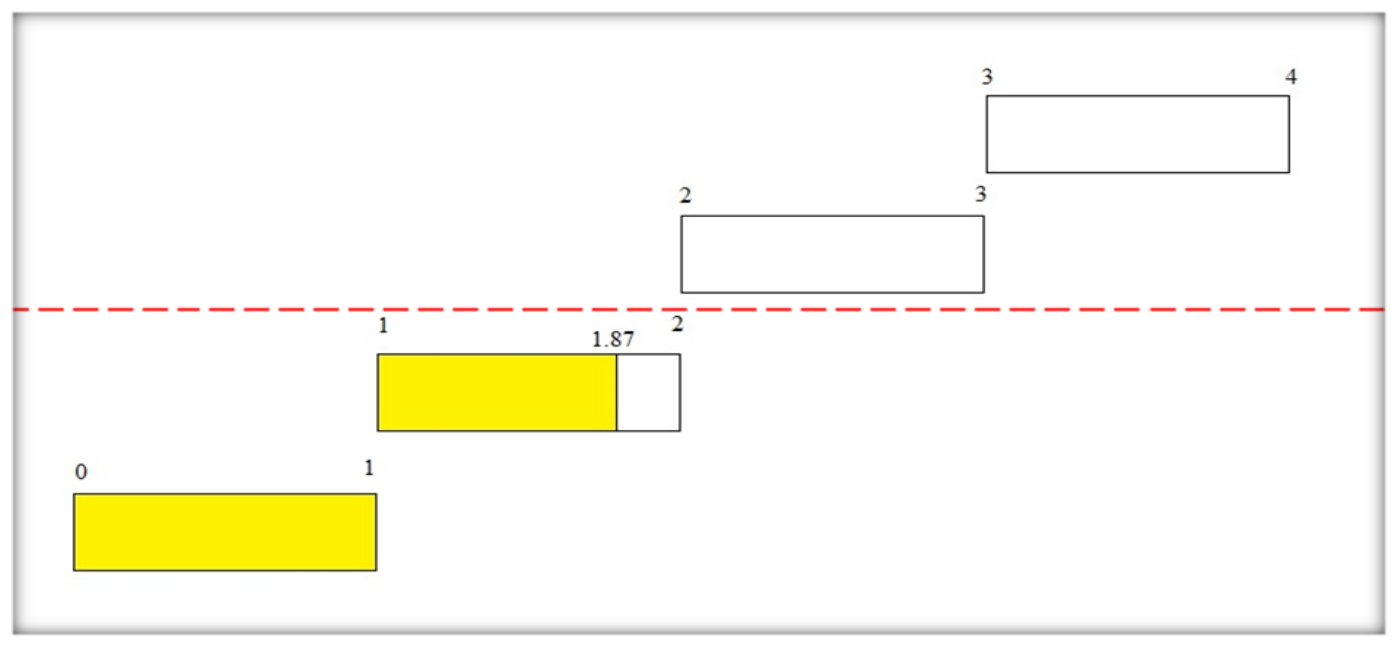

$($ Governance $=1.87)$

Figure 2: Staircase of governance for selected actors

\section{At The Level of Governance}

Tourism is a cross-cutting activity involving all actors. However, in our case, the involvement and participation of local actors in decision-making related to development policies appears very weak.

Limited communication between agencies reveals a lack of coordination of tourism activity in the region. The recurrence of relative demands on the part of the local population reveals that appropriate solutions have not yet been found, but also that the information provided by the tourism and conservation actors has not been always understood. The dialogue between actors and inhabitants is practically non-existent; private tourism operators do not consult the local population on matters concerning this territory.

Regional policy has generally failed in its desire to coordinate and manage the activity through a way capable of sustainably enhancing regional and local resources. This brings to question the sustainability of this activity and the development of the sector for present and especially future generations.

\subsection{Governance: or the Dynamic of the Actors on the Territory of Zaghouan}

\subsubsection{Tourism in Zaghouan: A Barely Noticeable Offer}

The tourism offer in the Zaghouan region is practically non-existent. Currently there are only two accommodations located in the Zaghouan delegation; Dar Zaghouan, a cottage in a working farm and hotel "The nymphs" ranked three stars. In the rest of the Governorate of Zaghouan the 
tourism offer is also very limited, there is only one lodging "Ksar Ezzit" in Ben Saidane, in the delegation of Fahs; it is an agro-tourism accommodation, with a production of organic olive oil. The problem posed for the creation of accommodation is that the procedures of change of vocation of the land and the tourist uses permitted in the zones with agricultural vocation are very complex. It is therefore at the legislative and institutional level that the most important thing is to be done, because here again, new mechanisms must be put in place to facilitate the procedures for changing the vocation.

On the other hand, the spa industry in Zaghouan constitutes an important channel to exploit; the Jebel El Oust and Zriba hot springs are notorious destinations for water treatment and care, despite some deficiencies, usually due to a lack of investment in maintenance and innovation and implementation of a strategy and a specific plan to promote thermal tourism in the region.

The absence of a real strategy for the development of sustainable tourism, which would first be achieved by improving the reception and accommodation capacity (construction of rural lodges, etc.) and the development of hosting practices, is causing difficulties. It is also necessary to develop activities such as handicrafts and local productions, as well as catering, and to encourage the training of guides specialized in rural tourism (horse riding, hiking, hunting ...). Finally, through the advertising and marketing work carried out by sustainable tourism managers in the region, the creation of an image based on a specific territorial identity that targets a specific clientele.

\subsubsection{Emergence of New Guests}

However, in recent years, we have seen the emergence of a real sustainable tourism market, among the Tunisians themselves, as revealed in our surveys and interviews with professionals in the region. For them, Tunisians are even the main customers of sustainable tourism. It is generally a rather affluent social class who visits the region with its own vehicle, which allows travelling all the tourist sites. Beyond this, however, no statistical data are available from the Tunisian National Tourist Office (ONTT), which does not allow a serious assessment of the market share of this sustainable tourism in Zaghouan, or even whole Tunisia.

\subsubsection{The Interest of Local Associations and ONG}

Local associations consider that development requires diversification of the economic fabric and the multiplication of income-generating activities, which also includes sustainable tourism. They organize, with the support of international ONGs, short training courses. They create ecotourism clubs and delimit, recognize and test itineraries.

Several associations intervene in the region such as the Zaghouan Hiking Environment Association (AREZ), which offers hiking and themed hikes (archaeology, botany, raptor observation), Caving Club Zaghouan (representing the Speleology Club of the Zaghouan Youth House and the Zaghouan Speleology Association). They don't organize activities for tourists, but do activities with members of the association and with experts, also with other clubs or foreign speleological associations; the Association "Sport Pour Tous Zaghouan", organizes in collaboration with the Tunisian Association for the Protection of Nature and Environment 
(ATPNE) an eco-trail (half marathon), which brings together a large number of sportsmen and spectators, presenting a truly successful sports festival in a unique nature in Tunisia; the association NESRI, in turn celebrates the Festival of wild roses whose beneficiaries are farmers and craftsmen and promotes the practice of wild roses, and the valorisation of its derivatives.

\subsubsection{Establishment of Socio-Professional Networks and Convergence of Interests}

In turn the private sector is motivated by economic reasons. Its objective is to satisfy tourists and their expectations in terms of services, activity and security in order to guarantee a sufficient occupancy rate for the profitability of its business. With a rather positive environmental record, it must also ensure that new social requirements are met.

Over time, tourist inbounds understood that they need to network at the local level, especially with local associations to ensure the passage of tourists to their establishments throughout the year. An inter-professional partnership has thus been established.

It can be noted that the owner of Dar Zaghouan, the most widespread accommodation in the area is one of the founders of the Association Alternative Tourism.

The experiences of these local professionals have pushed them to become the new leaders of local development, through associations. Their social and economic success places them among decision-makers at the regional level.

The membership of these new tourism professionals in civil society (local associations) will allow a rapid socio-political ascent and a certain authority in the public debate. These new elites will build inter-communal relations around their professional tourism interests but also their political interests.

\subsubsection{Low Capacity for Tourism from the Bottom Up}

The local population has not been able to adequately take advantage of the resources because of their low education and technical level. This population expects the state, through government agencies or through ONGs, to put in place a policy or development projects related to sustainable tourism. The scarcity of personal and public initiatives and, above all, the lack of resources in this region, hamper the movement. "The initiative does not come from below, it is expected that it comes from above, which seriously hampers the development of tourism and, even more, its permanence". (Berriane and Aderghal, 2012).

On the other hand, the desire of young people to improve their living conditions leads them to leave the countryside in order to find paid jobs in the city. The rural exodus thus empties the villages of its young people. The aging population is no longer able to subsist autonomously and some traditional knowledge is no longer transmitted. We cannot place ourselves in a dynamic of local development that is nevertheless essential in the field of sustainable tourism. 


\section{Conclusions \& Recommendations}

The Zaghouan region is indeed an intersection of public interest, especially for local actors. The recognition of the importance of this heritage by the various participants results in a greater and more diversified commitment and actions to safeguard the site. However, it remains that these multiple actions are carried out isolated. This lack of synergy can only make the overall scope of these actions ineffective, hence the need for concerted action between the various actors to improve the effectiveness of local development actions. In fact, the initiatives that multiply here and there that try to accompany the state through ONGs and development projects are sometimes inconsistent and the multiplication of actors requires collective governance, unfailing coordination and above all an integrated and integral approach to all the stakeholders of a given territory.

It is, in fact, a question of promoting genuine governance capable of mobilizing and involving the actors in a situation. Regulating a shared vision presupposes accommodations, compromises, conventions and partnerships that work as close as possible to tourism sights. From this point of view, the development of the region, in accordance with the conclusions on sustainable development and the principles that sustainability requires, is multidimensional. In order to better manage sustainable tourism projects, the indicators to be constructed, as indicated in this research, must be designed as close as possible to local realities to capture the quality required of this new tourism in order to build indicators of good governance in the field of sustainable tourism.

\section{Acknowledgements}

The author are deeply thankful to Professor Hichem Rejeb, for his dedication and for all the efforts he made in the development of this article through constructive and insightful comments or suggestions, which allowed them to improve the content and the presentation of the paper. The authors are also grateful to all the actors that participated in the elaboration of the grid for their collaboration, especially the associations and the tourism professionals and also Sousse University for the financial support.

\section{References}

[1] Berriane Mohammed Aderghal Mohammed. (2012). "TOURISME RURAL, GOUVERNANCE TERRITORIALE ET DEVELOPPEMENT LOCAL EN ZONES DE MONTAGNES.” Centre d'Études et de Recherches Géographiques(CERGéo), 108p.

https://www.academia.edu/2419001/Tourisme_rural_gouvernance_territoriale_et_d\%C3\%A9velo ppement_local_en_zones_de_montagnes

[2] Breton Jean-Marie. (2009). "AIRES PROTEGEES, GETION PARTICIPATIVE DES RESSOURCES ENVIRONNEMENTALES ET DEVELOPPEMENT TOURISTIQUE DURABLE ET VIABLE DANS LES REGIONS ULTRAPERIPHERIQUES.” Études caribéennes. https://etudescaribeennes.revues.org/3560

[3] Centre d'études sur les réseaux, les transports, l'urbanisme et les constructions publiques (CERTU). (2006). "PRENDRE EN COMPTE LE DEVELOPPEMENT DURABLE DANS UN PROJET, GUIDE D'UTILISATION DE LA GRILLE RST02. MINISTERE DES TRANSPORTS, DE L'EQUIPEMENT, DU TOURISME ET DE LA MER.” 64p. 
[4] Ferchichi Wahid. (2011). "EVALUATION DU CADRE JURIDIQUE ET INSTITUTIONNEL RELATIF 0 L'ECOTOURISME AT AUX AIRES PROTEGEES EN TUNISIE.” Agence espagnole pour la coopération internationale au développement (aecid). 66p.

[5] Coopération Technique Allemande (GTZ). (2007). "ETUDE STRATEGIQUE SUR LE DEVELOPPEMENT DE L'ECOTOURISME EN TUNISIE." 98p. http://www.environnement.gov.tn/fileadmin/medias/pdfs/dgeqv/ecotourisme_proj2_2.pdf

[6] Hammed Nizar. (2015). "LE TOURISME RURAL AU SERVICE DU DEVELOPPEMENT REGIONAL EN KROUMIRIE (TUNISIE): ENTRE POTENTIALITES LOCALES ET REALITES DU DEVELOPPEMENT DURABLE." Thèse de doctorat en géographie, Université Clermont Ferrand II, 400p.

[7] Maali Hanen. (2015). "LE TOURISME EN TUNISIE ET LA PRISE EN COMPTE DU DEVELOPPEMENT DURABLE: LE CAS DU TOURISME SAHARIEN.” Thèse de doctorat en géographie, Université Clermont Ferrand II, 357p.

[8] Riahi Mohamed. (2006). "PROGRAMME D'ACTION REGIONAL DE LUTTE CONTRE LA DESERTIFICATION DU GOUVERNORAT DE ZAGHOUAN. Ministère du Développement Régional et de la Planification." 99p.

[9] Sioud salma. (2013). "VERS UNE DEMARCHE GLOBALE D'ECOTOURISME APPLICABLE AU PARC NATIONAL JEBEL ZAGHOUAN." Mémoire de master, Institut Supérieur Agronomique de Chott Meriem, 110p.

[10] Theys Jacques. (2002). "LA GOUVERNANCE ENTRE INNOVATION ET IMPUISSANCE, CAS DE L'ENVIRONNEMENT." Dossier 2 | 2002: Gouvernance locale et Développement Durable. https://developpementdurable.revues.org/1523\#entries

*Corresponding author.

E-mail address: sioudsalma@gmail.com 